\title{
A Critique of The Civilising Rationale: Strategies for producing marginalisation*
}

\author{
Carlos del Valle-Rojas \\ UNIVERSIDAD DE LA FRONTERA \\ carlos.delvalleđaufrontera.cl \\ ORCID: 0000-0002-9905-672X
}

Received: 06/02/2019

Accepted: 01/10/2019

\begin{abstract}
The radical distinction between civilization and barbarism used in the discourse of the national states of Chile and Argentina during the second half of the XIX century, not only was used to justify the genocidal military intervention of the territories inhabited by the mapuche indigenous from the south of both countries; but also inaugurated a conflictive relationship that remains to the present. The main objective of the paper is to identify the scope of the "civilization project" initiated during the second part of the 19th century and expressed during the $20^{\text {th }}$ and $21^{\text {st }}$ centuries through different and broad forms of marginalization, both ethnic and -by extension- immigrant, the criminal and LGBT+ groups; in such a way that it is a historical, systematic and institutionalized process of producing marginalities, which considers various production strategies of the intimate enemy, especially from the cultural industry available in each time.

The results show how "marginal/marginalized" is produced and reproduced, through policies of death, dispossession, inclusion/exclusion, in a constant relationship from moral, criminal and neoliberal rationalities.
\end{abstract}

Keywords: civilization project, critique of moral and civilizing reason, production of the marginalities.

Corresponding author: Carlos Del Valle-Rojas. Departamento de Lenguas, Literatura y Comunicación. Facultad de Educación, Ciencias Sociales y Humanidades (Universidad de la Frontera) Francisco Salazar 01145 (Temuco-Chile).

Suggested citation: Del Valle-Rojas, C. (2019) A Critique of The Civilising Rationale: Strategies for producing marginalisation. Debats. Journal on Culture, Power and Society, 4, 161-170. DOI: http://doi.org/10.28939/iam.debats-en.2019-13

\footnotetext{
* The CONICYT-Chile PIA/ANILLOS SOC180045 project and the CONICYT-Chile FONDECYT 1150666 project funded this study.
} 


\section{INTRODUCTION}

When the politician, intellectual, and former Argentine President Domingo Faustino Sarmiento wrote Facundo o Civilización y Barbarie in 1874, it sparked a public and political discourse of such performative power (in both semantic and in practical terms) that it played a key role in the occupation of the southern lands of the Mapuche Indians by the Nation States of Chile and Argentina. The work had a deep symbolic, cultural, and political impact: "Facundo is the clamour of modern culture against the feudal twilight [...] Sarmiento's words seem to issue from the heavens in a kind of latter-day Sinaí" (Ingenieros, 2000: 191). It also had great economic impact given that it suggested the inevitable: "The tropical interaction between symbolisation on the one hand and economic and linguistic production on the other [because] language and currency are measures. Language is the measure of Man's ideas [...] while currency is the measure of objects' value" (Shell, 1981: 14 and 16).

As a result, Sarmiento's work sheds light on many things, including the conflictiveness seen today. This does not arise from the work's literary nature - which is wholly 'modernist' - but rather because of its relationship with bourgeois ideology and practices (Rodríguez, 2003), from with the book both stems from and expresses. This helps explain why Facundo still echoes today. Its continued relevance mainly stems from an ability to transcend the mindset of the era - that of a utopia of 'free subjects' (that is, of non-barbarians) - whose supposedly libertarian ethos hid a desire to replace the workforce - the purpose actually underlying the 'civilising project' (del Valle, 2018b). Sarmiento's writings betray the racial ideas underlying his work:

The development of reason follows the same rules. Savages' skulls are all the same size and all savages think the same, which is to say that they do not think at all, they merely feel. In a state of barbarism, one can already see skull differences, and the emergence of opinions among those few individuals who begin to wonder [...] A sea of blood will be needed to put both races on an equal footing and many illustrious white men will fall victim to the knives wielded by races pursuing their vendetta as they shout "Death to the filthy, cheating whites!" (Sarmiento, 1915: 195 and 260)

The foregoing is an example of the criteria that were to be used in institutional measures to reduce the native question to a merely ' racial' issue, and in which the 'civilising project' of the Nation States became part of an on-going effort to neutralise, dispossess, and criminalise Indians and thus write them off politically. Without political recognition, there could be no autonomy or emancipation because Indians were given no scope for changing their lot or negotiating in the drawing up of plans. This flagrant de-politicisation explains why the Mapuche Indians have been kept marginalised ever since the mid-20 ${ }^{\text {th }}$ Century.

This paper first presents a theoretical-conceptual approach to delve into how the civilising rationale ${ }^{\mathbf{1}}$ not only imposed a marginal status on the Mapuches but how this has lasted until today. In the process, we identify the features of the historical and systematic institutional processes that conjured up an image of Indians as the home-front foe and the special role played by the discourses of a hegemonic cultural industry in making it stick (del Valle, 2019, 2018a, 2018b, 2018c, 2017, 2016). Last, a model is proposed for analysing the discourses of this 'civilising' matrix, especially in fostering forms of marginalisation.

\section{THE CIVILISING RATIONALE AND THE PRODUCTION OF A HOME-FRONT FOE AND FORMS OF MARGINALISATION BY THE CULTURAL INDUSTRY}

Since the second half of the $20^{\text {th }}$ Century, the cultural industry has played a key role in conveying the ideas

1 Considering the importance of the discourses present in the 'civilising project', in my view the notion of 'civilising rationality' reveals those 'enlightened' aims attributed by their authors in the sense that the 'rationality' of the 'civilising project' justifies the 'irrationality' of their practices. That is because acceptance of this contradiction opens the door to combining massacres and management, or more precisely, massacre management. 
underlying the Nation State's 'civilising project'. This project has been hawked as 'truth', which after its proclamation, must be made accessible to "all intelligences, overcome public resistance to the passions and interests raised against the notion and become part of peoples' most deeply-held beliefs" (Sarmiento, 1850: 64). In this respect, it is clear that there was a need to articulate the 'civilising project' and the media of the period.

In addition, we understand the 'civilising project' as a hegemonic social, cultural, political, and media narrative whose purpose was the imposition an all-white, masculine, 'enlightened' South American ideology that automatically marginalised many groups (Indians, blacks, women, the uneducated lower classes, and so on). In a broad sense, we consider the 'civilising drive' in opposition to the natural world (Elías, 1988), in which what is seen as 'civilised' or 'barbaric' constitutes a naturalisation, fetishisation, or discrimination arising from interactions. The notion of a 'civilising project' is thus a purely social construction and in this case stemmed mainly from an elitist, aristocratic notion of society, and from hegemonic aims.

Here, one should also consider the cognitive and cultural measures used to further this project, for example, in the model used for interpretative frameworks (Adorno, 1988). In this respect, we can see two approaches at work, one resting on similarity and the other on opposition. Together, they form part of a wholly binary logic in which one part is accorded greatly inferior status.

The point of departure was Greek Philosophy, which saw all complex forms as a duality in which one natural element prevailed over another: perfection over imperfection; strength over weakness; virtue over vice [where] the subject by recognising himself also recognises the other. The urge to define the nature of 'the other' stems from the subject's need to define himself and his own limits. As a cultural process, the subject may see the creation of 'the other' as an inescapable demand, be he coloniser or a native. The discourses created on - and for the colonial subject did not stem merely from a desire to understand 'the other' but rather from the need for the subject to distinguish himself in hierarchical terms from 'the other'. (Adorno, 1988: 61 and 66)

In addition, the cultural industry (Yúdice and Miller, 2008; Horkheimer and Adorno, 2007; Zallo, 1988) is shaped by any body or entity whose work is oriented towards the production and reproduction of ideas and information from both the standpoints of material exchanges and the social relation of meaning. Thus the cultural industry includes the production of both fiction and non-fiction. In the case of literature, we are especially interested in its ideological content:

Literature has not always existed. The discourses that we apply today to literary works reflect a historical reality that only emerged from a given set of strict (historical) conditions. These conditions were of an ideological nature characterising 'modern' or 'bourgeois' formations in general. (Rodríguez, 2003: 5)

In the case of The Press, we are interested in its mass production, its ability to produce and distribute symbolic contents, its consumer (reader) orientation and the role it plays in ideological and social reproduction (Zallo, 1988).

One of the main modes and strategies adopted by the cultural industry is its representation of the Mapuches as the home-front foe of the Nation State and as a hurdle to the latter's civilising project. Here, a home enemy is constructed by Nation States as the 'threat from within'. In the past, the threat has been interpreted as a neighbour, a fellow-countryman, or an ally but what really counts is that he is one's 'enemy'. The fabrication of an enemy is not only a social, military, or cultural deed, it is also a political one that becomes part and parcel of a true institutional conscience that has great power to reproduce itself, allowing the Nation State to maintain an unlimited social role and to endlessly proselytise: "Modernity, like modern science, could live with everything except irrelevance and a limited, non-proselytising 
social role" (Nandy, 1983: 102).

While the path taken in conjuring up this enemy has been a slow, winding one, it has reached its goal. It began with highly metaphorical, stigmatising discourses spread through the cultural industry, especially in the literature of the elite and the hegemonic Press. Stigmatisation has always been a highly effective strategy because when the coloniser states that the native is weak, he is suggesting that protection [of the kind proposed by the colonist] is needed because of the Indian's perverse nature, base instincts, sadism, and thieving ways. This image is then used as a pretext for strong policing and harsh 'justice'. (Memmi, 1971: 3)

\section{Figure 1}

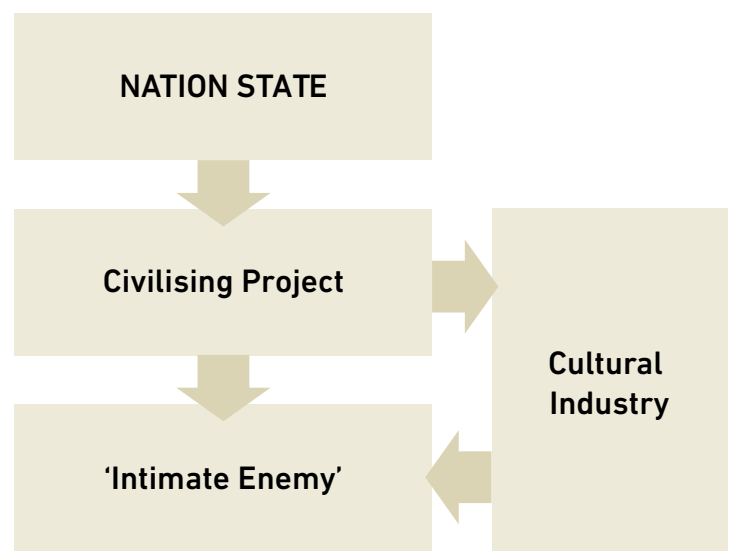

The strategy for producing an enemy (author's scheme).

SOME OF THE STRATEGIES USED FOR THE 'CIVILISING

\section{PROJECT'}

Within the overall strategy for producing an enemy, the 'civilising project' was supplemented by other radical approaches that were gradually implemented in the $19^{\text {th }}, 20^{\text {th }}$, and $21^{\text {st }}$ centuries. In a nutshell, all these cases involved producing and reproducing psychological strategies for political ends. Rhetoric was to play a central role in pursuing a social strategy.
The aim was to elicit emotional reactions stemming from the interaction between a set of affective impulses and social pressures [...]to spread the structure, uses, and the prevailing social norms. In this context, rhetorical strategies served to shape, consolidate, and give cohesion to the dominant system, and were thus clearly of great practical value. (Galiñanes, 2009: 112)

The first of these strategies is the 'Death Policy' (Mbembe, 2011), incorporating a set of policies designed and implemented by Nation States during the second half of the $19^{\text {th }}$ Century which decided who had to die in order to consolidate the 'civilising project'. These decisions were linked to the need to exercise sovereignty and thus they reveal a constant kind of relationship that would be nuanced by the powers that be depending on the context. It was a relationship in which bureaucracy and the use of terror in the ruthless exercise of sovereignty went hand-in-hand: "Here, we can see the first syntheses between massacres and bureaucracy in an incarnation of Western rationality" (Mbembe, 2011: 36).

The second strategy combined dispossession and depoliticisation through a set of policies drawn up and put into effect by the Nation States. This involved finding ways to take the Indians' supposedly 'barren' land away from them. Here, we understand this dispossession as:

A process that, through the exercise of violence and duress, permanently deprives individuals and/or communities of their acquired rights, their human dignity, lands, property, and social, economic, and cultural rights (Sánchez, 2009: 30).

Last and without prejudicing the measures described above, the most effective policy against the enemy within is to systematically portray its marginalisation, turning this into the norm. This is the case of "Criminal Law applied to the enemy" (Jakobs and Cancio, 2003), an expression that refers to a set of special or exceptional laws created or invoked against a group of persons who are seen not as citizens but as foes. The main feature of such Criminal Law it is 
that is prospective rather than retrospective. In other words, it covers what might happen and is thus of a 'preventative' nature. That is why the sentences stemming from it are so severe and involve the suspension of due process and other constitutional guarantees.

Such use of Criminal Law is tantamount to a declaration of war by the judiciary on individuals considered to pose an especially grave threat [...] and goes hand-in-hand with ruthless instrumentalisation of security measures for dealing with certain kinds of danger. In using these instruments, the State does not speak of citizens but rather threatens its enemies [...] the identification of an infractor as an enemy by the Criminal Law is neither a designation of 'the other' nor an identification of him as a source of danger that needs to be neutralised. Instead, it is recognition of the agent's normative power to characterise the 'infractor' as perverse by demonising him. (Jakobs and Cancio, 2003: 86,87 and 88 )

A notable feature of such Law is the moment of its emergence, which is when Nation States bring it into being. This foundational instant coincides with what Derrida terms "terrible moments" because such laws are usually accompanied by "suffering, crimes, and torture" stemming from what Derrida calls the "mystic nature" of such junctures:

It is the Law that suspends Law itself. It breaks with established law to create a new body of law. This juncture, this epoché, this founding or revolutionary moment for the Law is a moment when law itself is held in abeyance. (Derrida, 1997: 92)

In a more specific setting, the production of the Indian as a foe of the Nation State is based on a moral, criminal, neo-Liberal rationale (Misse, 2018; Vieira, 2017) - in other words, on a set of supposedly rational arguments based on frames of reference as to what was considered moral, normal, and modern at the time for a given case.
Figure 2

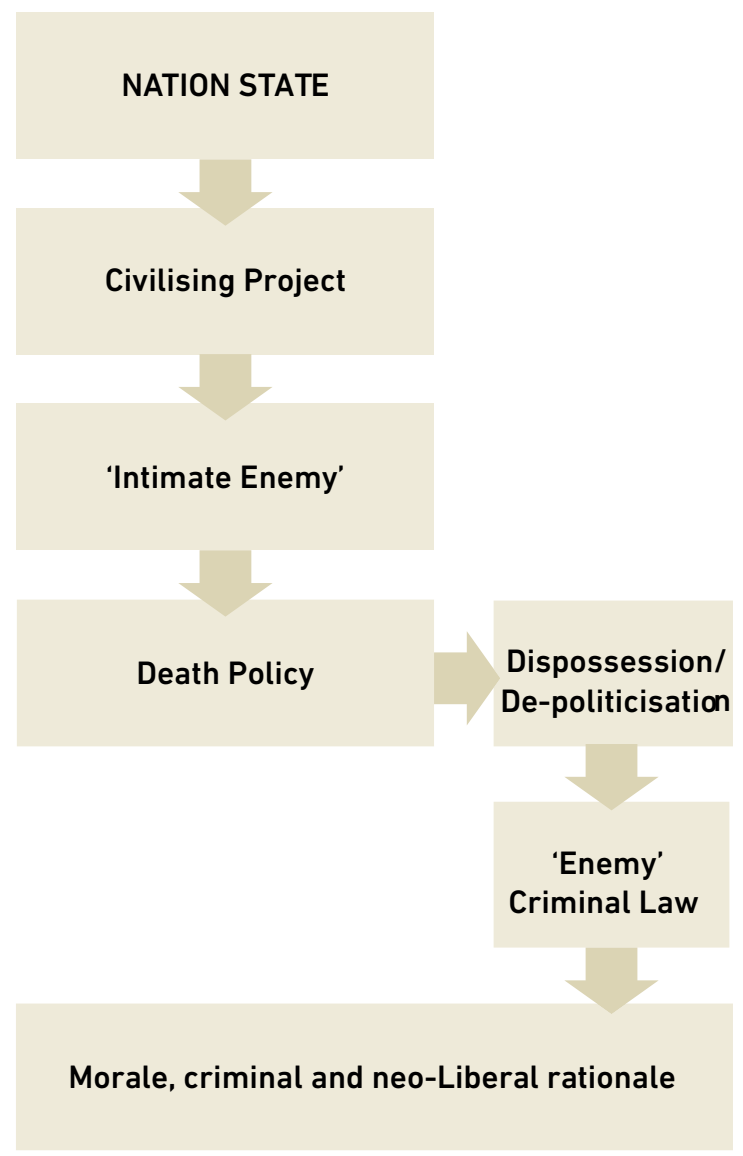

Various strategies for producing an enemy (Author).

\section{THE SCOPE OF THE CIVILISING PROJECT}

It is clear that what was begun in the mid- $19^{\text {th }}$ Century was a project that was political, economic and military in scope. In Arjiropolis o la capital de los Estados confederados del Río de La Plata (1850), Sarmiento laid the foundations of this project, namely "that Trade and Industry is the source of wealth for any State" and that "among the political powers of the State are those of "making peace and waging war".

This civilising rationale was also applied in the succeeding centuries, albeit with nuances. Nevertheless, the core remained the same, namely different forms 
of conjuring up and neutralising an enemy by pursuing a strategy of marginalisation.

One of the most interesting aspects for this research is to grasp the systematic way in which Indians were turned into an 'enemy within' over time. This was achieved both through the discourse on the Nation State and through the cultural industry. The impact was not only broad and general on the relationships between the societies and cultures involved but also affected the daily lives of the natives. This is where the moral, criminal, and neo-liberal rationale sprang from (Misse, 2018, 2014, 2010). Its source was the complex interplay of certain social and cultural groups in which deep intervention of a historic, systematic, and institutionalised nature led to great self-conviction regarding the naturalness of criminal behaviour. Nevertheless, one needs to bear in mind that crime springs from a given social interaction. Hence the ethical meaning attributed to certain deeds by "moral entrepreneurs" (Becker, 2009) and power groups so that certain kinds of behaviour (but not others) can be labelled as 'criminal' or 'delinquent'. The next step is then to label and punish the individuals/groups exhibiting said behaviour. That is why the meaning of crime is endlessly debated because it is criminal subjection that spawns the criminal subject.

This process has many implications. On the one hand, the criminalised subject reacts just as colonised subjects did when others identified them with nature, passion, the feminine, and with domestic, rural, and pagan spheres. The natives so typified were contrasted with the values of the colonists who were considered to enshrine: culture; reason; masculinity; public and courtly spheres; chivalry; Christianity. (Adorno, 1988: 66)

On the other hand, criminal subjection evidences a struggle for the heart and mind of the other. It betokens another kind of struggle covering the production and reproduction of the status assigned to the underdog and resistance to it through endless self-questioning by the colonised. In this process, the subject is torn between: (1) what he was and what he wanted to become; (2) what he is now and what he is turning into. Both inflict great emotional pain and lead to self-alienation. To be fully cured of these ills, the subject needs to put an end to his alienation yet this can only be brought about by a complete end to colonisation, even during times of rebellion. (Memmi 1971, 28)

Subjection is a complex phenomenon because it both implies subordination to the powers that be and the subject's resignation to his lowly status.

Criminal subjection refers to a social process through which negative expectations of individuals and groups become so commonplace and widely accepted that they are taken as gospel truth and as justification for said subjection. [...] The crime is reified and enshrined in the subject supposedly responsible for the stigmatised crimes. [...] There is a fundamental difference between (1) a discrediting attribute (stigma, labelling, negative stereotype, prejudice) and (2) social expectation that 'the other' both wishes and is able to do evil. When it comes to defining sociability patterns, this difference is especially salient in the former case given that conflict may arise from an attribute whereas in the latter, the attribute arises from expectations of conflict (Misse, 2018: 191, 192).

\section{TOWARDS A DISCOURSE ANALYSIS MATRIX ON MARGINALISATION}

We use this specific theoretical-conceptual framework to understand the discourse produced by the cultural industry in constructing Indians as the mortal enemy of the Nation State. We put forward a matrix to capture and analyse that discourse.

First, we consider the aforesaid discourse as a social practice that:

a) is part of a social process of discursive production and takes a given position within it and through self-reference; 


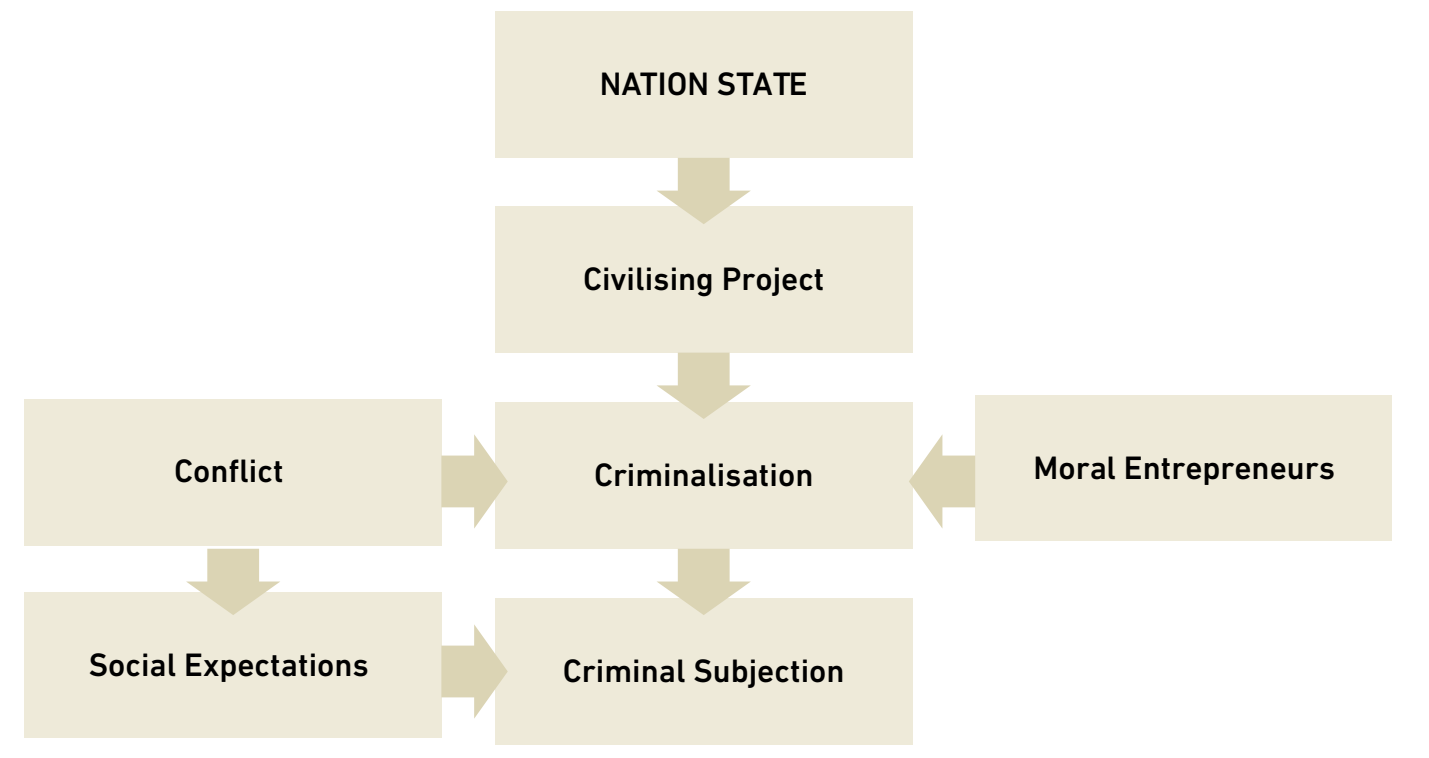

Production of criminal subjection (Author).

b) directly or indirectly covers a pre-existing "cultural premise" that is linked to a system of dominant (or subordinate) representations and values whose complex, contradictory articulation defines the ideology of this society;

c) is presented as a ritualised and regulated social practice by apparatus within the framework of a given setting. (Giménez, 1981: 125)

Second, we consider two expressions of the discourse within the cultural industry, to wit literature and the press. One centres on the national literatures, which in the The West coincide with the political construction of nationalism and that are also heirs of the same ideological and spiritual framework that gave rise to the Liberal Revolution and the Capitalist Order. Here, nationalist literature has weaker links with the aesthetics of the art form than it does with nationalist politics (Mariátegui, 2000). The other centres on the hegemonic press and basically covers the papers used by 'the powers that be' to amplify and echo their discourses for the political construction of nationalism.
This Press is used as an ally to popularise the message and acts as a political player in its own right.

Third, we examine the organisation of cultural projects by the ruling classes. These projects vary depending on the period, and reveal both continuities and changes:

1) The culture of the elite. This takes up some of the habits of the aristocracy and l'Ancien Régime - that is to say one characterised by prestige, privilege, differentiation, and appropriation.

2) The distributive project, which focuses on literacy, education, journalism, etc. In this project, the goal of 'the powers that be' is to boost the cultural level of the working classes but only in order to serve their own interests.

3) The goal is to turn a profit. Mass literacy, urban concentration, social restructuring, and industrialisation create new target audiences. A 
cultural consumer market springs up that offers Capitalists succulent investment opportunities. Culture is thus transformed into a powerful industry, which gives rise to the emergence of mass culture (Ford, 2016: 72 and 73).

Last, we use the idea of producing forms of marginalisation as a way of highlighting the performative nature of the discourse. This covers not only the discourse's scope for referring to a given reality but also for constructing it in an arbitrary, self-interested fashion. Thus marginalisation is the result of a social, cultural, political, and economic process focusing on the desire to exclude previously singled out groups or those entering the country. The strategies used, their order, and intensity varies depending on the case. Making enemies of and criminalising target groups leads to marginalisation because it is not sufficient to label ones foes and criminals, they have to be pushed to society's fringes.

Here, we propose a matrix incorporating the aforementioned concepts, and operationalised as categories for gathering and analysing discourses:

\section{CONCLUSIONS}

The goal of the study was to draw up a theoreticalconceptual approximation to a historic phenomenon, namely the systematic, institutionalised marginalisation of Indians. This approximation also sheds light on the exclusion of other groups in today's world, examples being immigrants, prisoners, and various LGBT groups. All these groups form part of our study, which adopts a multi-country perspective, as does the Proyecto Anillo de Investigación en Ciencias Sociales $y$ Humanidades [Ring Research Project in The Social Sciences and The Humanities]: "Converging Horizons: Production, Mediation, Reception and Effects of Representations of Marginality" (SOC180045), which is currently under way in Chile, Argentina, and Brazil).

The strategies we observe since the $19^{\text {th }}$ Century to the present range from 'Death Policies', appropriation measures, and criminalisation strategies through various special laws making up a body of Criminal Law targeting the enemy. All this was made possible by the 'civilising project' and while its origins are clear, it still holds sway in our societies today in the form of a social, cultural, economic, political, and media

Figure 4

\begin{tabular}{|c|c|c|c|c|c|c|}
\hline & $\begin{array}{l}\text { Death } \\
\text { Policy }\end{array}$ & $\begin{array}{l}\text { Disposse- } \\
\text { ssion Policy }\end{array}$ & $\begin{array}{l}\text { 'Enemy' } \\
\text { Criminal } \\
\text { Law }\end{array}$ & $\begin{array}{l}\text { Moral, } \\
\text { criminal } \\
\text { and } \\
\text { neo-Liberal } \\
\text { rationale }\end{array}$ & $\begin{array}{l}\text { Moral, } \\
\text { criminal, } \\
\text { and } \\
\text { neo-Liberal } \\
\text { subjection }\end{array}$ & $\begin{array}{l}\text { Marginali- } \\
\text { sation }\end{array}$ \\
\hline $\begin{array}{l}\text { Category/ } \\
\text { Description }\end{array}$ & $\begin{array}{l}\text { Explicit or } \\
\text { implicit } \\
\text { reference } \\
\text { to policies } \\
\text { aimed at } \\
\text { eliminating } \\
\text { a group }\end{array}$ & $\begin{array}{l}\text { Explicit or } \\
\text { implicit } \\
\text { reference } \\
\text { to policies } \\
\text { aimed at } \\
\text { disposse- } \\
\text { ssing groups } \\
\text { of their } \\
\text { lands }\end{array}$ & $\begin{array}{l}\text { Explicit or } \\
\text { implicit } \\
\text { reference to } \\
\text { exceptional } \\
\text { or special } \\
\text { laws } \\
\text { targeting } \\
\text { groups }\end{array}$ & $\begin{array}{l}\text { Explicit or } \\
\text { implicit } \\
\text { reference } \\
\text { to moral } \\
\text { values to } \\
\text { discredit or } \\
\text { stigmatise } \\
\text { the group }\end{array}$ & $\begin{array}{l}\text { Explicit or } \\
\text { implicit } \\
\text { reference to } \\
\text { persuasive } \\
\text { moral } \\
\text { arguments } \\
\text { against the } \\
\text { group }\end{array}$ & $\begin{array}{l}\text { Explicit or } \\
\text { implicit } \\
\text { reference } \\
\text { to the } \\
\text { group's } \\
\text { marginalised } \\
\text { status }\end{array}$ \\
\hline
\end{tabular}


discourse of a hegemonic nature. The goal is always the same - to use various strategies to impose the ideology of a white, masculine, enlightened South America and to highlight and exalt it by contrasting it with marginal groups (Indians, blacks, women, the uneducated lower classes, and so forth).

These issues require eternal vigilance and are of great interest to Social Research. Basically, the presence of myriad diverse socio-cultural groups - characteristic of today's complex societies - together with the role played by a media industry serving certain lobbies give rise to "deep uncertainty about exactly who is 'one of us' and who is not. This is true to such an extent that the various marginalisation and exclusion practices we see constitute ways of tackling this uncertainty "dismembering the body of the suspected culprit" (Appadurai, 2007: 18).

We have thus seen how these marginalised subjects are produced by resorting to diverse psycho-political strategies ranging from moral, criminal, and neo-Liberal rationales imposed by certain social groups with the goal of excluding other groups. We have yet to discover the distinctive features of today's strategies towards this end, and to grasp the interactions among the various groups, especially those between "established and marginalised groups" (Elías and Scotson, 2016).

\section{BIBLIOGRAPHIC REFERENCES}

Adorno, R. (1988). El sujeto colonial y la construcción cultural de la alteridad. Revista de Crítica Literaria Latinoamericana, año 14 (28), p. 55-68.

Appadurai, A. (2007). El rechazo de las minorías. Ensayo sobre la geografía de la furia. Barcelona: Tusquets Editores.

Becker, H. (2009). Outsiders: hacia una sociología de la desviación. Buenos Aires: Siglo XXI.

del Valle, C. (2016). Genealogía crítica del conflicto entre el Estado de Chile y el Pueblo Mapuche a partir de las producciones discursivas de la prensa, las sentencias penales en los tribunales de la región de La Araucanía y otros relatos. Hacia una historiografía de la exclusión mediática y jurídico social. In J. Pinto (ed.), Conflictos étnicos, sociales y económicos en la Araucanía, 1900-2014 (p. 247-282). Santiago de Chile: Pehuén.

del Valle, C. (2017). La producción del «enemigo interno» en la industria cultural en Chile: De la discriminación a la «sujeción criminal». In M. García and F. Maniglio (ed.), Los territorios discursivos de América Latina. Interculturalidad comunicación e identidad (p. 8-26). Quito: Ediciones CIESPAL.

del Valle, C. (2018a). La producción del enemigo íntimo en la industria cultural chilena: Crítica a la certeza moral, la razón neoliberal y la sujeción criminal. In D. Caldevilla (ed.), Perfiles actuales en la información y en los informadores (p. 51-68). Madrid: Serie Ediciones Universitarias Editorial TECNOS.

del Valle, C. (2018b). La simbolización de la industria y la industrialización de la cultura, a propósito de la producción del libro en Chile. In C. Maldonado, C. Peralta, C. del Valle e Í Salgado (ed.), Libros de la lluvia. Estado actual de las editoriales independientes y universitarias del sur de Chile. (p. 23-45). Temuco: Ediciones Universidad Católica de Temuco.

del Valle, C. (2018c). El rol de la industria cultural en el proyecto civilizatorio: Hacia una matriz de análisis del discurso del enemigo íntimo y el sujeto criminal. In S. Poliszuk and A. Barbieri (ed.), Medios, periodismo y actores en escenarios de conflictos sociales. Río Negro: Editorial de la Universidad Nacional de Río Negro. [In Press].

del Valle, C. (2019). La criminalización radical del enemigo como estrategia del estado nacional y las élites en la lucha por las tierras indígenas. In Á. Arévalo, G. Vilar and M. García (ed.), Comunicación y cambio social (p. 155-165). Barcelona: Tirant lo Blanch.

Derrida, J. (1997). Fuerza de ley. El «fundamento místico de la autoridad». Madrid: Tecnos.

Elías, N. (1988). El proceso de la civilización. Investigaciones sociogenéticas y psicogenéticas. Mexico: FCE.

Elías, N. and Scotson, J. (2016). Establecidos y marginados. Una investigación sociológica sobre problemas comunitarios. México DF: Fondo de Cultura Económica. 
Ford, A. (2016). 30 años después. 1973: las clases de Introducción a la Literatura en Filosofía y Letras y otros textos y relatos. La Plata: Universidad Nacional de La Plata.

Galiñanes, M. (2009). Atrocidades, maldades, enemigos sangrientos y zahúrdas de Plutón: estrategias retóricas para la representación de la alteridad. In P. Begrand (ed.), Representaciones de la alteridad, ideológica, religiosa, humana y espacial en las relaciones de sucesos, publicadas en España, Italia y Francia en los siglos XVI-XVIII. BESANZÓN: PRESSES Universitaires de Franche-ComTÉ.

Giménez, G. (1981). Poder, estado y discurso. Perspectivas sociológicas y semiológicas del discurso político-jurídico. México: Universidad Nacional Autónoma de México.

Horkheimer, M. and Adorno, T. (2007). Dialéctica de la Ilustración. Madrid: Akal.

Ingenieros, J. (2000). El hombre mediocre. Recuperado de http://educ.ar

Jakobs, G. and Cancio, M. (2003). Derecho penal del enemigo. Madrid: Civitas Ediciones.

Mariátegui, J. C. (2000). El florecimiento de las literaturas nacionales. In A. Fernández (comp.), La invención de la nación. Lecturas de la identidad de Herder a Homi Bhabha. Buenos Aires: Ediciones Manantial.

Mbembe, A. (2011). Necropolítica seguido de Sobre el gobierno privado indirecto. Santa Cruz de Tenerife: Editorial Melusina. Memmi, A. (1971). Retrato del colonizado, precedido por retrato del colonizador. Madrid: Cuadernos para el diálogo.

Misse, M. (2018). Una identidad para el exterminio. La sujeción criminal y otros escritos. Temuco: Ediciones UFRO.

Misse, M. (2010). La acumulación social de la violencia en Río de Janeiro y en Brasil: algunas reflexiones. Revista Co-herencia, 7(13), p. 19-40.

Misse, M. (2014). Sujeição criminal. In R. Sérgio de Lima (org.), Crime, polícia e justiça no Brasil (p. 204-212). São Paulo: Editora Contexto.

Nandy, A. (1983). The intimate enemy. Loss and recovery of self under colonialism. Oxford: Oxford University Press.

Rodríguez, J. C. (2003). El escritor que compró su propio libro. Para leer El Quijote. Barcelona: Debate.

Sánchez, G. (2009). El despojo de tierras y territorios. Aproximación conceptual. Bogotá: Área de Memoria HistóricaComisión Nacional de Reparación y Reconciliación (CNRR).

Sarmiento, Domingo (1845). Civilización i Barbarie. Vida de Juan Facundo Quiroga. Aspecto físico, costumbres i habitos de la Republica Arjentina. Santiago: Imprenta del Progreso.

Sarmiento, D. (1915). Conflicto y armonías de las razas en América. Buenos Aires: La Cultura Argentina.

Sarmiento, D. (1850). Arjiropolis o la capital de los Estados confederados del Río de La Plata. Solución de las dificultades que embarazan la pacificación permanente del río de La Plata, por medio de la convocación de un Congreso, y la creación de una capital en la isla de Martín García, de cuya posesión (hoy en poder de la Francia) dependen la libre navegación de los ríos, y la independencia, desarrollo y libertad del Paraguay, el Uruguay y las provincias argentinas del litoral. Santiago de Chile: Imprenta de Julio Belin i Ca.

Vieira, E. (2017). Teoria psicopolítica. A emancipação dos aparelhos psicopolíticos da cultura. Temuco: Ediciones UFRO.

Yúdice, G. and Miller, T. (2008). O copyright: Instrumento de expropriação e resistência onde se encontram a economia política e os estudos culturais. In C. Bolaño (org.), Comunicação e a crítica da economia política. Perspectivas teóricas e epistemológicas (p. 173-191). São Cristóvão: Editora UFS.

Zallo, R. (1988). Economía de la comunicación y la cultura. Madrid: Akal.

\section{BIOGRAPHICAL NOTE}

Tenured Professor at Universidad de La Frontera, Chile. Research Fellow, University of Groningen, The Netherlands. PhD in Communication from Universidad de Sevilla, Spain. Advanced Post-doctoral programme in Contemporary Culture. Universidade Federal do Rio de Janeiro, Brazil. Director of PhD programme in Communication and Director of the journal Perspectivas de la Comunicación, Universidad de La Frontera, Chile.

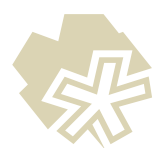

